\title{
The Impact of Using Instructional Strategy Based on The Brain's Natural Learning Systems for Special Needs Students in the Inclusive Classroom
}

\author{
Rasmitadila, Widyasari, Teguh Prasetyo \\ Elementary School Teacher Education, Djuanda University, Bogor, West Java, Indonesia; \\ E-mail address rasmitadila@unida.ac.id
}

\begin{abstract}
The problem that occurs in learning in inclusive classrooms is that teachers have not been able to design learning effectively that can accommodate the needs of all students, including students with special needs. The purpose of this study is to explore the opinions of the general teacher (GT) and special teacher (ST) about the impact of using instructional strategies based on the brain's natural learning system for special needs students (SNS) in inclusive classes. Data were collected through classroom observations and interviews with both types of teachers and analyzed using thematic analysis. The research produced three main themes, namely, learning motivation, learning experience, and social interaction. Instructional strategies based on the brain's natural learning system have a positive impact on SNS in instruction. It has fostered enthusiasm and enthusiasm for learning, providing learning experiences in finding knowledge according to its characteristics, and increasing social interactions that can increase SNS confidence when communicating with others. Instructional strategies based on the brain's natural learning system are effectively used in inclusive classes. They are expected not only to be used in inclusive elementary school levels but also for higher levels.
\end{abstract}

Keywords: instructional strategies, the brain's natural learning system, inclusive classes, special needs student

\section{INTRODUCTION}

Instruction in inclusive classrooms requires effective strategies so that instructional strategies that have been set can be adequately achieved. All students, including special needs students (SNS) must also experience learning success. For that general teacher (GT) and special teacher (ST) must be able to work together so that SNS can achieve the success of learning. In an inclusive classroom with the conditions of characteristics and diversity possessed by students, requires teachers to be able to design instruction that can be carried out by general students (GSs) and SNSs (Saloviita, 2018; Rasmitadila et al., 2020).

During this time, the instructional strategy used by GT has not provided a fair opportunity for SNSs, which can bring out its best ability to learn according to its characteristics, weaknesses, 
and strengths (Curran and Petersen, 2017). GT still cannot understand the aspects of SNS, pay less attention to SNS, and tends to submit problems faced by SNS to ST. This condition does not provide an opportunity for SNS to develop with GS. More SNS activities are carried out individually so that the ability to interact, motivation to learn with GS is less. If learning is done in groups, it can increase the spirit of learning to SNS (Mezquita-Hoyos et al., 2018).

For this reason, GT needs to design instructional strategies that can be effective and provide opportunities for all students to develop. To achieve an instructional strategy, as well as long-term impacts that are very useful for all students, including SNS (Arbouet Harte, 2010). One instructional strategy that can have a positive impact on SNS in learning is an instructional strategy based on the brain's natural learning system.

This study aims to explore the opinions of general and special teachers about the impact of the use of instructional strategies based on the brain's natural learning system on SNS in the inclusive classroom.

\section{LITERATURE REVIEW}

\subsection{Natural brain learning system.}

The brain's natural learning system is learning based on five learning systems, namely emotional learning systems, social learning systems, cognitive learning systems, physical learning systems, and reflective learning systems (Given, 2002). An emotional learning system is a learning system that places teachers as mentors, which creates a conducive classroom climate, making teacher-student and student relationships a warm relationship. The teacher functions to help foster a desire to learn, have a strong desire to be the best in the future, by carrying out challenging learning, relevant following the knowledge students have. A social learning system, placing students as part of a group with a focus on interaction with others by collaborating in a learning community, working together in making decisions, and solving problems that can foster student and teacher creativity in learning. A cognitive learning system, placing the teacher into the role of facilitator while students as problemsolvers and decision-makers. Providing learning space in a position that offers opportunities for students to explore knowledge, problem-solving, and decision making based on the learning process that has been done. A physical learning system, involving all class members in physical activity, or psychomotor and tactile on a topic being studied. The reflective learning system places the teacher to understand the learning styles, strengths, and weaknesses of students after going through the learning process. For students, this learning system illustrates, what must be improved from a lesson, measuring abilities and fostering strengths into talents that can be developed in the future.

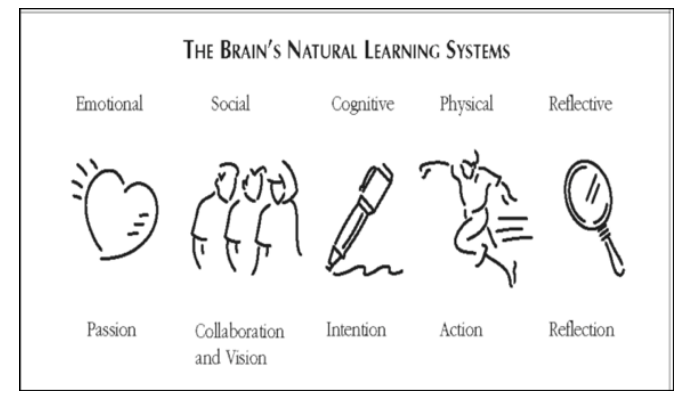

Fig. 1 The Brain's Natural Learning Systems(Given, 2002)

2.2 Instructional strategies based on the brain's natural learning system

The instructional strategy model based on the natural learning systems of the brain is one way to design learning in inclusive classes. Plan learning steps, learning methods that fit the characteristics 


$$
\text { Vol. } 1 \text { (1), 1-7 }
$$

The Impact of Using Instructional Strategy Based on The Brain's Natural Learning Systems for Special Needs Students

Rasmitadila, Widyasari, Teguh Prasetyo

of inclusive classrooms, the use of different instructional media, easy to use by students. Besides, instructional materials can be accessed with each student - the use of the time that can be estimated by the teacher in one learning activity. The learning process is based on all five learning systems that are interrelated and used in every learning activity from the beginning to the end of learning.

Table 1. Instructional Strategy Based on the Brain Natural Learning System in the Inclusive Classroom

\begin{tabular}{|c|c|c|c|c|c|c|c|c|}
\hline No & $\begin{array}{l}\text { Material / } \\
\text { Topic of } \\
\text { learning }\end{array}$ & $\begin{array}{l}\text { The } \\
\text { brain's } \\
\text { natural } \\
\text { learning } \\
\text { systems } \\
\text { aspect } \\
\end{array}$ & Steps / Sequence of instructions & Methods & Media & Materials & $\begin{array}{l}\text { Assess } \\
\text { ment }\end{array}$ & $\begin{array}{l}\text { Time } \\
\text { allocatio } \\
\mathrm{n} \\
\text { (minute) }\end{array}$ \\
\hline & & & & & & & & \\
\hline \multicolumn{9}{|c|}{ Early learning activities } \\
\hline 1 & $\begin{array}{l}\text { "Me } \\
\text { and my } \\
\text { ideals." }\end{array}$ & $\begin{array}{l}\text { Emotional } \\
\text { Learning } \\
\text { System }\end{array}$ & $\begin{array}{l}\text { - GT Plays some videos in front of the } \\
\text { class. } \\
\text {-Teacher brings paperboard that } \\
\text { contains jobs } \\
\text {-The teacher asked each student what } \\
\text { the models of each student } \\
\text {-The teacher explains the purpose of } \\
\text { the lesson }\end{array}$ & $\begin{array}{l}\text {-inquiry } \\
\text { - lecturer } \\
\text {-discussion }\end{array}$ & $\begin{array}{l}\text {-In focus } \\
\text {-Paper carton } \\
\text {-Board plank }\end{array}$ & $\begin{array}{l}\text {-Short film } \\
\text {-Students Books }\end{array}$ & - & $15^{\prime}$ \\
\hline \multicolumn{9}{|c|}{ Main Event } \\
\hline & & $\begin{array}{l}\text { Social } \\
\text { learning } \\
\text { system }\end{array}$ & $\begin{array}{l}\text {-GT divides students into six groups } \\
\text {-GT divides each one of the } \\
\text { illustrated papers into each group. } \\
\text {-Each group will make one sentence } \\
\text { according to the picture } \\
\text {-Each picture will be distributed to } \\
\text { other groups, to make another } \\
\text { sentence }\end{array}$ & $\begin{array}{l}\text { - Game } \\
- \\
\text { Discussion }\end{array}$ & -Paper & \begin{tabular}{|c}
-Color \\
drawing \\
-Carton \\
illustrated
\end{tabular} & Rubric & $20 '$ \\
\hline & & $\begin{array}{l}\text { Physical } \\
\text { learning } \\
\text { system }\end{array}$ & $\begin{array}{l}\text {-Each group members practice } \\
\text { reading sentences (poems) that have } \\
\text { been made } \\
\text {-GT shows some pictures of animals } \\
\text { to one group and demonstrates the } \\
\text { characteristics of animals other } \\
\text {-group guess }\end{array}$ & $\begin{array}{l}\text { - Exercise } \\
\text { with a } \\
\text { friend } \\
\text {-Game } \\
\text {-Guess } \\
\text { image }\end{array}$ & $\begin{array}{l}\text {-Display } \\
\text {-Paper Text } \\
\text {-Book }\end{array}$ & $\begin{array}{l}\text {-Carton display } \\
\text {-Text-book }\end{array}$ & Rubric & $20^{\prime}$ \\
\hline & & $\begin{array}{l}\text { Cognitive } \\
\text { learning } \\
\text { system }\end{array}$ & $\begin{array}{l}\text {-GT asks each group member to look } \\
\text { for animal traits } \\
\text {-Each group presents the results of } \\
\text { discussions with group members }\end{array}$ & -Discussion & $\begin{array}{l}\text {-In focus } \\
\text { - Internet }\end{array}$ & $\begin{array}{l}\text { - Internet } \\
\text {-Book }\end{array}$ & Rubric & $20^{\prime}$ \\
\hline \multicolumn{9}{|c|}{ Closing Activities } \\
\hline & & $\begin{array}{l}\text { Reflective } \\
\text { learning } \\
\text { system }\end{array}$ & $\begin{array}{l}\text {-GT explains about poetry and animal } \\
\text { growth } \\
\text {-GT provides a reward for each group } \\
\text { and motivates them to be better on the } \\
\text { next topic }\end{array}$ & $\begin{array}{l}\text { Discussions } \\
\text {-Lecture }\end{array}$ & Star Card & - & Points & $15^{\prime}$ \\
\hline & $\begin{array}{c}\text { Reflection } \\
\text { Advantag } \\
- \\
- \\
- \\
\text { Weakness } \\
- \\
- \\
-\end{array}$ & $\begin{array}{l}\text { Lecturer to } \\
\text { es: } \\
\text { Each stude } \\
\text { Have seen } \\
\text { The studer } \\
\text { discussion } \\
\text { Instruction } \\
\text { es and impr } \\
\text { Reduces tl } \\
\text { More med } \\
\text { Provide su }\end{array}$ & $\begin{array}{l}\text { learning: } \\
\text { active learning } \\
\text { thad to engage in activities group of } C \\
\text { al media easy for each student to use } \\
\text { ovements: } \\
\text { ie dominance of general students in the } \\
\text { provided } \\
\text { pport and encouragement to SNS to be }\end{array}$ & $\begin{array}{l}\text { ideo mention } \\
\text { GS would pro } \\
\text { e discussion } \\
\text { e more active }\end{array}$ & $\begin{array}{l}\text { s his ideals } \\
\text { vide the oppor } \\
\text { o that the role }\end{array}$ & $\begin{array}{l}\text { ty for SNS to } h \\
\text { t be regulated }\end{array}$ & a vo & n group \\
\hline
\end{tabular}




\section{RESEARCH METHODOLOGY}

This study uses qualitative research to describe the impact of learning for SNS when using the instructional strategies of the brain's natural learning system in inclusive classes. The use of qualitative research is used because it can explore people's opinions or thoughts in understanding research questions in-depth on the topic of being studied (Kothari, 2004). Participants involved in this study consisted of 3 GT and 3 ST originating from 2 inclusive elementary schools in Bogor Regency. GT and ST are teachers who teach in inclusive classes with teaching experience between 3-7 years. Meanwhile, the SNS involved in the study consisted of 6 people, indicated in the category of a slow learner, autistic, and ADHD students. Data collection was done by classroom observation and open interviews with GT and ST. Before conducting the research, GT and ST were given brief training on instructional strategies based on the brain's natural learning system. Learning is carried out three times using an instructional strategy based on the brain's natural learning system for 1.5-2 hours for each learning. Researchers record all learning activities from the beginning to the end of learning. The results of this observation are field notes that have been transcribed in detail. In addition to observation, data collection is also done by semi-structured interviews and open-ended questions. Interviews were conducted following interview guidelines that had been made by researchers. The contents of the interview were about teacher perceptions about the implementation of the brain's natural learning system. It's related to the implementation time of learning, the sequence/steps of instruction, methods, and media, as well as teaching materials used in learning.

The data uses a Thematic Analysis, which produces several main themes.

\section{FINDING AND DISCUSSION}

This study uses an instructional strategy based on the brain's natural learning system as a learning model to facilitate inclusive teachers to help SNS in learning in inclusive classes. During the reduction process, three main issues emerged that were obtained from inclusive teachers. The following themes describe the findings supported by verbatim evidence.

\subsection{Motivation to learn}

Students with special needs have characteristics, and barriers to learning motivation tend to be low. This condition can be seen from the enthusiasm and enthusiasm of SNS at the beginning and implementation of learning (Brophy, 2017; Komarudin, 2017). Teachers must be able to arouse the enthusiasm and interest of SNS so that learning becomes more interesting and can be followed by SNS (Turner et al., 2015). The brain's natural learning system has helped GT and ST in arousing the enthusiasm and enthusiasm of SNS when learning takes place. The use of exciting learning methods and media such as playing roles and watching videos about famous personalities gives a real picture to SNS, that through learning that is relevant to their daily lives SNS can become what he wants in the future. SNS has a higher desire to learn compared to previous learning because the conditions and classroom atmosphere are mutually supportive. One of GT's opinions is below:

"I see SNS is very enthusiastic in learning because classmates support it. He is more confident to learn and motivated to learn, whereas previously, it was challenging for SNS to start learning. "

Instructional strategies based on the brain's natural learning system help SNS foster learning desires and motivate SNS. Also, to be able to achieve the learning goals targeted by GT. 


\subsection{Learning experience}

Instructional strategies based on the brain's natural learning system provide opportunities for all students, including SNS, to explore broad knowledge and ease of access. The knowledge gained was designed by GT and ST and implemented by all students in conducive and pleasant conditions (Bradfield and Myers, 1996; Hamilton, 2018). Group learning activities have provided opportunities for SNS to be able to issue opinions, make joint decisions in togetherness with GS. This condition has a positive impact on SNS, which has been very closed and not confident in learning with GS. One of the ST opinions below illustrates the SNS experience in group learning with GS:

"By group learning, SNS gets the opportunity to express their opinions. GS appreciates SNS opinions, and this provides a good learning experience because it will influence SNS in achieving their best ".

Instructional strategies based on the brain's natural learning system have provided opportunities for SNS to learn to make decisions, solve problems, and increase confidence to develop with GS. This gives an excellent impact on the SNS to gain knowledge because of the obstacles possessed by the SNS.

\subsection{Social interaction}

One of the weaknesses and limitations of SNS in learning is social interaction. Social interaction between SNS and GS occurs in learning when joint activities take place, such as group work in the context of problem-solving one subject topic, as well as physical activities that require a team (van de Pol and Elbers, 2013; Lindström and Mondada, 2009). GT designs instructional strategies so social interactions can occur using methods that require mutual interaction, such as in small group discussions(Yutapratama and Syamsi, 2019; Rahmayanti et al., 2017). Each group member communicates with each other to understand the opinions of other members. For SNS, this activity has a positive impact and is progress to be more confident in their abilities even though they have obstacles. This opinion was expressed by one of the ST below:

"In my opinion, the impact of having group work is perfect for SNS, because he can express opinions and want to communicate with his friends."

Instructional strategies based on the brain's natural learning system are five learning systems that are interrelated and can have a positive impact on SNS. Emotional learning systems can arouse SNS motivation; cognitive, social, physical, and reflective learning systems can have a positive impact so that SNS can gain learning experiences and social interactions (Dr. Rasmitadila et al., 2019; R. Rasmitadila et al., 2019). The use of the five learning systems designed in the form of instructional strategies with the use of methods, media, and teaching materials that are varied and easily accessible has a generally positive impact on the development of SNS, both academically and non-academically.

\section{CONCLUSION AND FURTHER RESEARCH}

Instructional strategies based on the brain's natural learning system has had a positive impact on SNS. The use of varied learning methods, easy-to-use learning media, and accessible teaching materials make it easy for SNS to achieve the learning goals set by the teacher. The positive impact felt by SNS can foster motivation to learn, add to the learning experience, and increase social interaction. Instructional strategies based on the brain's natural learning system are expected to be used not only 
by inclusive teachers at the elementary school level but also at the higher levels because it is very effectively used in inclusive classes.

\section{REFERENCES}

Arbouet Harte, H., 2010. The Project Approach: A Strategy for Inclusive Classrooms. Young Except. Child. 13, 15-27. https://doi.org/10.1177/1096250610364355

Bradfield, C.D., Myers, R.A., 1996. In practice: Enriching the student learning experience through community service learning: In practice: Enriching the student learning experience through community service learning. Campus 1, 28-29. https://doi.org/10.1002/abc.6190010107

Brophy, J.E., 2017. Fostering Student Learning and Motivation in the Elementary School Classroom, in: Paris, S.G., Olson, G.M., Stevenson, H.W. (Eds.), Learning and Motivation in the Classroom. Routledge, pp. 283-306. https://doi.org/10.4324/9781315188522-15

Curran, C.M., Petersen, A.J., 2017. Handbook of research on classroom diversity and inclusive education practice. IGI Global.

Given, B.K., 2002. Teaching to the brain's natural learning systems. ASCD.

Hamilton, A., 2018. The Need for Student Engagement: The Need for Student Engagement. New Dir. Teach. Learn. 2018, 21-31. https://doi.org/10.1002/t1.20288

Komarudin, K., 2017. The Relationship Between Intelligence and Learning Motivation on Childrens With Special Need in Inclusive Elementary School. Guid. J. Ilmu Pendidik. Psikol. Bimbing. Dan Konseling 7. https://doi.org/10.24127/gdn.v7i1.806

Kothari, C.R., 2004. Research methodology: Methods and techniques. New Age International.

Lindström, A., Mondada, L., 2009. Assessments in Social Interaction: Introduction to the Special Issue. Res. Lang. Soc. Interact. 42, 299-308. https://doi.org/10.1080/08351810903296457

Mezquita-Hoyos, Y.N., Sanchez-Monroy, M.H., Morales-Martinez, G.E., Lopez-Ramirez, E.O., Reyna-Gonzalez, M. del R., 2018. Regular and Special Education Mexican Teachers' Attitudes toward School Inclusion and Disability. Eur. J. Educ. Res. 7, 421-430.

Rahmayanti, D., Rasmitadila, R., Prasetyo, T., 2017. PENGGUNAAN METODE KERJA KELOMPOK DALAM INTERAKSI SOSIAL BAGI SISWA AUTISME. Didakt. TAUHIDI J. Pendidik. GURU Sekol. DASAR 4, 101. https://doi.org/10.30997/dt.v4i2.896

Rasmitadila, Widyasari, Prasetyo, T., Rachmadtullah, R., Samsudin, A., Riana Suryanti Tambunan, A., 2019. Design of Instructional Strategy Model Based on the Brain's Natural Learning System (MS-SiPAO) in Inclusive Classrooms in Higher Education. Univers. J. Educ. Res. 7, 2352-2360. https://doi.org/10.13189/ujer.2019.071113

Rasmitadila, R., Samsudin, A., Prasetyo, T., 2019. Teacher-Students' Instructional Interactions Analysis (TSIIA): A Case Study in Inclusive English Classrooms in Indonesia. Int. J. Interdiscip. Educ. Stud. 14, 1-22. https://doi.org/10.18848/2327-011X/CGP/v14i01/1-22

Rasmitadila, R., Widyasari, W., Humaira, M.A., Tambunan, A.R.S., Rachmadtullah, R., Samsudin, A., 2020. Using Blended Learning Approach (BLA) in Inclusive Education Course: A Study Investigating Teacher Students' Perception. Int. J. Emerg. Technol. Learn. IJET 15, 72-85.

Saloviita, T., 2018. How common are inclusive educational practices among Finnish teachers? Int. J. Incl. Educ. 22, 560-575.

Turner, J.C., Kackar-Cam, H.Z., Trucano, M., 2015. Teachers Learning How to Support Student Interest in Mathematics and Science, in: Renninger, K.A., Nieswandt, M., Hidi, S. (Eds.), Interest in Mathematics and Science Learning. American Educational Research Association, pp. 243-257. https://doi.org/10.3102/978-0-935302-42-4 14

van de Pol, J., Elbers, E., 2013. Scaffolding student learning: A micro-analysis of teacher-student interaction. Learn. Cult. Soc. Interact. 2, 32-41. https://doi.org/10.1016/j.1csi.2012.12.001 
Yutapratama, N., Syamsi, I., 2019. Social Interaction Through Traditional Games in Special Needs Children, in: Proceedings of the International Conference on Special and Inclusive Education (ICSIE 2018). Presented at the Proceedings of the International Conference on Special and Inclusive Education (ICSIE 2018), Atlantis Press, Yogyakarta, Indonesia. https://doi.org/10.2991/icsie-18.2019.80 